Contents list available at IJRED website

Int. Journal of Renewable Energy Development (IJRED)

Journal homepage: http://ejournal.undip.ac.id/index.php/ijred

\title{
Wind Power Generation in India: Evolution, Trends and Prospects
}

\author{
M.F. Khan* and M.R. Khan
}

Electrical Engineering Department, Aligarh Muslim University, INDIA

\section{Article history:}

Received July 24, 2013

Received in revised form Sept 17,2013 Accepted Oct 13, 2013 Available online

\begin{abstract}
In the present context of shrinking conventional resources coupled with environmental perils, the wind power offers an attractive alternative. Wind power generation in India started way back in early 1980s with the installation of experimental wind turbines in western and southern states of Gujarat and Tamil Nadu. For first two decades of its existence until about 2000 the progress was slow but steady. In last one decade Indian wind electricity sector has grown at very rapid pace which has promoted the country to the fifth position as largest wind electric power generator and the third largest market in the world. The galvanization of wind sector has been achieved through some aggressive policy mechanisms and persistent support by government organizations such as MNRE and C-WET. This paper articulates the journey of Indian wind program right since its inception to the present trends and developments as well as the future prospects.
\end{abstract}

Keywords: c-wet, mnre, renewable energy, wind power, wind turbines.

\section{Introduction}

India is home to more than 1.26 billion of global population and generation of enough resources for the inclusive growth of the country has always been a big challenge for policy makers. Electric energy being one of the necessities for poor and rich alike remains one resource which has always been over burdened. This is in-spite of substantial gains made by the country in terms of installed capacity enhancement post independence. In 1950 the total installed capacity of the country was a meagre $2300 \mathrm{MW}$ which has increased to about 212.828 GW by Jan'2013. The economic thrust experienced by India over the last decade has lead to electricity demand being surged at a much rapid rate than ever before. During the FY 2011-12, In-spite of a global economic recession the power demand in the country kept increasing. As a consequence, the power outages are a common practice and close to $40 \%$ population has no access to grid power (GWEC 2012). As per the policy documents, power demand of the country will triple during the period 2005-2030(GWEC
2012). All this means that a very robust and carefully planned power policy, both short term and long term, is required to expand the power generation/delivery mechanism in order to keep up with the increasing demand and electrification of more villages.

The essence of 'sustainable development' stems from two fundamental approaches (Sanaeepur et al. 2013). First one may be termed as long term approach which requires substituting the existing technologies from those less dependent on hydro carbon based fuels. While the second idea of sustainable technology calls for the development of renewable sources of energy. Thus, power generation technologies have been under rigorous review all over the world since considerable period of time now. The development of renewable energy sources is a thrust area and the governments all over the world are constrained to promote them due to reasons such as diminishing coal reserves coupled with the environmental issues (Athanas \& McCormick 2013; Dahlquist et al. 2011; Chaubey \& Saket 2012). These concerns have lead to development of better and more efficient methods of tapping renewable sources of 
energy (Al-Majed, \& Fujigaki 2010). Apart from their environmental attributes and providing energy requirement reliefs, they also trigger creation of a huge amount of future oriented jobs (Hinrichs-Rahlwes 2013).

Out of all the sources of renewable energy wind is the oldest and most researched topic for the academicians and researchers alike. Wind Electricity Generation (WEG) has under gone very fast development in the last three decades (Kaldellis \& Zafirakis 2011; Okundamiya \& Nzeakoba 2012)from being an off grid power source for holiday homes and small village communities in Europe and America to a fully commercialized power generation industry all over the world. Realizing the potential of WEG India too has taken up the task of harnessing it as a priority policy issue.

The Indian wind electricity generation program began in late 1980s with the active assistance of some of the leading WEG countries in those days such as Netherland and Denmark (Earnest \& Tore 2011) along with the keen interest of Indian manufacturers such as Bharat Heavy Electricals Limited (BHEL). Although, in the initial phase the progress was slow but it remained steady due to the sustained efforts of government of India through its organization Ministry of New and Renewable Energy (MNRE). In the year 1997 MNRE took a decisive step for the development of wind energy in the country by setting up the first wind turbine test center, the Center for Wind Energy Technology (CWET) at Tamil Nadu, Chennai (Madras in those days). Ever since its inception C-WET has been responsible for dealing with $\mathrm{R} \& \mathrm{D}$ related issues pertaining to wind energy.

This paper is an endeavour undertaken to present a comprehensive analysis of Indian wind sector right since its inception to the present day and the challenges ahead of it. Its importance vis-à-vis meeting future demands and various initiatives being taken and proposed for increasing the wind generation capacity are also discussed. Besides, unleashing a detailed discussion on above issues one of the most important technical aspects of wind generation; choice of electrical generator for wind applications is also discussed along

with basic functioning of each.

\section{Evolution of Wind Power Generation Systems}

Ever since the inception of modern civilization, human race has undergone a great transition through countless life changing inventions. One of the greatest inventions ever achieved by human race is to learn the art of harnessing energy in its various forms. As per the available counts use of wind turbines for human welfare is as old as 200 B.C. In those times it was mainly used for driving ships, pumping water from reservoirs for irrigation, grinding of food grains and other simple but important applications for sustenance of life. However, it was much later in 1887 that a wind turbine was used for the first time for generating electricity. It was basically a wind turbine that was used for power generation by charging a dc battery for the holyday home of the inventor James Blyth in Marykirk, Scotland (Price 2005). The battery charging wind turbine of Blyth is depicted in Fig. 1(a). A little later in 1888 Charles F. Brush, the American inventor, built first ever automatic wind turbine for electricity generation in Cleveland Ohio USA (Carlin et al. 2003, Kaldellis \& Zafirakis 2011), depicted in Fig. 1(b). Subsequent to introduction wind turbine generators by Blyth and Brush further advancements in the designs of wind turbines were initiated by a numbers of inventors. Marcellus Jacobs introduced one of the most important wind turbine designs in the beginning of 20th century (Manwell et al. 2002). Afterwards, for the next 20 odd years most of the wind turbine designs evolved in horizontal axis designs. In 1922 the finish engineer S.J. Savonius brought out the Sovenius turbine and in 1931 Georges Darrieus developed the Darrieus turbine (Eriksson et al. 2008). Both Sovenius and Darrieus turbines were based on vertical axis designs and are considered standard for many subsequent VAWTs. However, all these machines were relatively lower rating $\mathrm{KW}$ machines. The first ever megawatt capacity wind turbine was developed in 1941. The 1.25 MW Smith-Putnam turbine depicted in Fig. 1(c) (Ahlstrom 2005) was installed in Vermont, USA (Gasch \& Twele 2012).

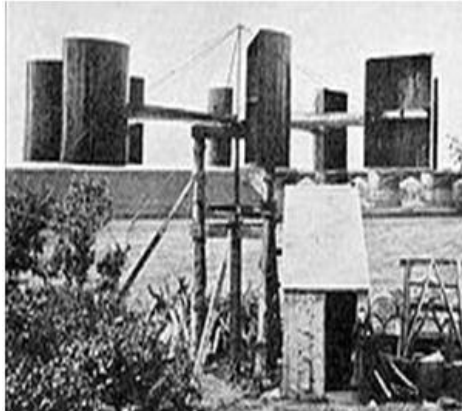

(a)

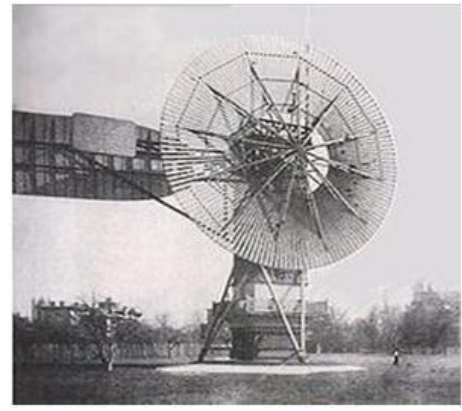

(b)

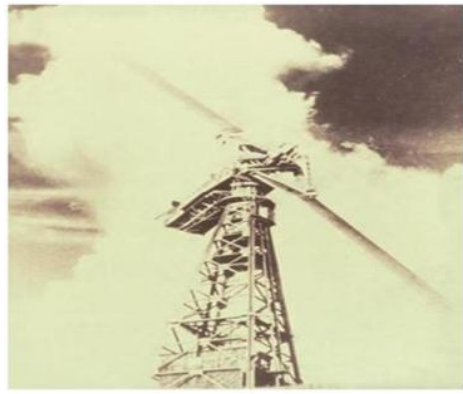

(c)

Fig. 1 Some of the earliest wind turbines built for electricity generation:

(a)Blyth's battery charging wind turbine. (b) Brush's automatic wind turbine. (c) First ever megawatt wind turbine the "Smith-Putnam" machine. 
The global wind power generation capacities have increased from 6,100 MW in 1996 to about $282.482 \mathrm{GW}$ by end of 2012 (GWEC 2013). Likewise, the generation capacities of wind turbines have increased monumentally, from few kilowatts capacity Wind Turbine Generation Systems (WTGS), today the largest capacity wind turbine Enercon E-126 installed in Poland is capable of generating about 7.5 MW of power on its own. The Gunsu wind farm of China is the largest on shore wind farm with capacity of more than 5000 MW (List of onshore wind farms, n.d) and is expected to be upgraded to $20000 \mathrm{MW}$ in the future. On the offshore front, the Greater Gabbard wind farm of UK has the distinction of being the largest off shore wind farm producing $504 \mathrm{MW}$ of power through 140 wind turbines (Anonymous, 2012). Off late, Japan has taken up the task of moving away from its dependence on nuclear power to renewable energy and in its endeavour is planning to build the largest off shore wind farm till date of the capacity of $1 \mathrm{GW}$ by using just 143 wind turbines in its Fukushima province (Bob 2013). The plant is proposed to be operational by 2020 . The total WEG installed capacities of some of the important wind power nations are given in Fig. 2.
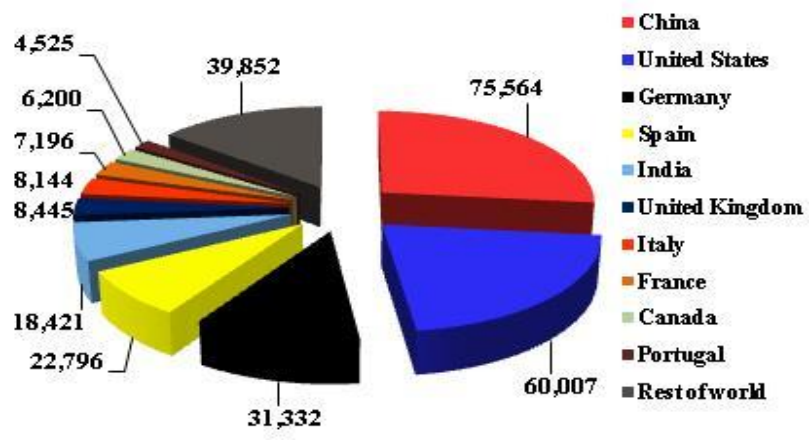

Fig. 2 Wind installed capacities (MW) of different nations by the end of 2012

\section{Wind Power Generation in India}

Fig. 3 depicts a wind farm in the Indian state Maharashtra, India. Indian wind energy program started in 1980s. In the initial stages of wind technology development India received substantial assistance from the countries such as Netherland and Denmark. However, the Danish assistance in this regard has been unparalleled and proved most beneficial for the promotion of wind power in India. The Danish International Development Agency (DANIDA) supported RISO Laboratory of Denmark carried out wind assessment studies in India in 1982 (Madsen 2013). One of the first ever wind plant was installed at Veraval, Gujarat with $40 \mathrm{KW}$ wind turbine through Dutch assistance (Earnest \& Tore 2011; Khan \& Khan 2013a). However, the turbine failed due to excessive wear. Subsequently, another attempt was made through imported wind turbines of Danish make Micon and DWT at Mandvi, Gujarat (Earnest \& Tore 2011). This system worked successfully and the wind energy program was set in motion. In the same period indigenous manufacturer Bharat Heavy Electricals Limited (BHEL got a wind farm installed at Mullakkadu, Tamil Nadu with 10 WTGS each of $55 \mathrm{kw}$ capacity, the overall capacity of the farm later increased to $1.15 \mathrm{MW}$ (Satyaraj 2013). In further developments, RISO under 'Renewable Energy Assistance' program with Government of India arranged for sourcing the delivery of hardware from Denmark for two more installations. One was a $4 \mathrm{MW}$ wind farm set up at Muppandal, Tamil Nadu and another in Lamba, Gujarat of 10 MW capacity. Further assistance of Danida and RISO kept coming in the form of activities such as arranging interactions between the Danish and prospective Indian manufacturers, training of the manpower etc. In 1990 another wind farm with Danish assistance was commissioned at Kayathar. However, the highest point of this relationship came in 1998 when Danida supported RISO Lab's cooperation in wind technology and infrastructure development in India culminated in the setting up of India's first ever wind turbine test station and the Centre for Wind Energy Technology (CWET), in Chennai. Since its inception C-WET has become a catalyst for all R\&D and policy related activities in the country. The C-WET is mandated to be a consolidated focal point for wind power development in India. Some of the prime objectives of C-WET defined by the government are enumerated as (Centre for Wind Energy Technology 2013a) :

- Act as the technical focal point for wind power development in India

- To develop and expand the facilities and capabilities, evolve strategies, promote, conduct, co-ordinate and support research and development programs.

- To analyze and assess wind resources based on the available data.

- To prepare and establish standards including guidelines, procedures, protocols for design, testing and certification of wind power systems.

- To establish world class facilities, conduct and coordinate testing of complete wind power systems, sub-systems and components.

- To accord type approval / type certification which verifies conformity with safety related requirements as per standards and guidelines.

- To monitor the field performance of wind power systems, sub-systems and components.

- To undertake human resource development program for the personnel working in the wind energy sector. 
- To promote commercial exploitation of know-how, know-why results and offer various consultancy services to the customers.

- To promote the development and commercialization of any other wind energy systems including stand-alone systems.

In spite of the interest evoked by success some of the earliest wind installations, the progress of wind generation in India remained slow and sluggish in comparison with the established players such as USA and Denmark. This trend continued till about late $90 \mathrm{~s}$. However, with the dawn of new century, India started to emerge as a new global economic power. The economic prosperity meant an increase in power demand by all the sectors in the country. To feed this increasing demand of power the country had to look for all possible avenues of generating more power besides the conventional ones afresh. Thus, wind energy generation got a fresh lease of life through various policies introduced by the government for the promotion of renewable energy sector. In this regard the electricity act 2003 (EA-2003) proved to be instrumental for power sector in India on the whole. It was subsequent to the passage of this act that government announced lots of supportive measures or wind power sector. The result of these policies is represented by excellent capacity additions of wind power in 10th and 11th plan periods. For instance, the wind generation target set for 10th plan (2002-2007) was $1500 \mathrm{MW}$ where as actual realization was 5427 MW. Similarly, for the 11th plan (2007-2012) the targeted wind generation was $9000 \mathrm{MW}$ while achieved figure was 10,260MW. To give a specific breakup of wind power generation pattern in last decade, the year wise wind generation capacity addition of the country since 2002 is shown in Fig. 4, while Fig. 5 illustrates share of wind energy in total renewable energy generation in India for the period April to August '2012.

As per the statistics released by Central Electricity Authority (CEA) of India the total installed generation capacity of India as on 31/01/2013 is given as 212.828 GW with the contribution of various sources as shown in Fig. 6. Out of the total installed capacity the share of renewable energy sources is about $26.920 \mathrm{GW}$ of which the contribution of wind power is about $18.551 \mathrm{GW}$, that is more than $70 \%$

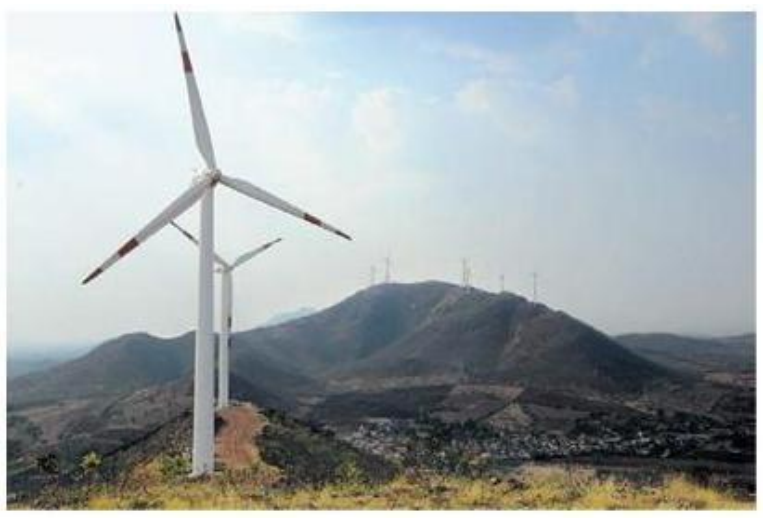

Fig. 3 A Wind farm in Kapatgudda, Karnataka

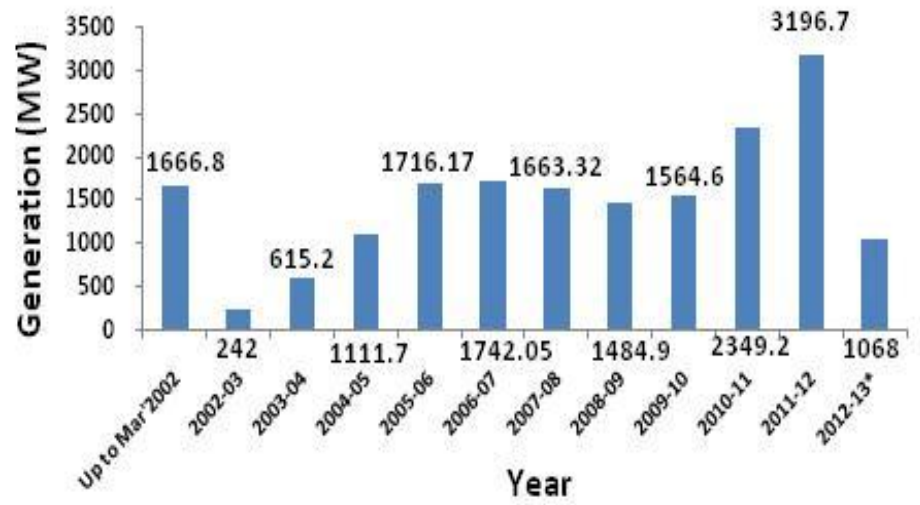

Up to Dec'2012

Data Source: cwet.tn.in Fig. 4 Year wise wind power installed capacity (in Megawatt) in India since 2002.

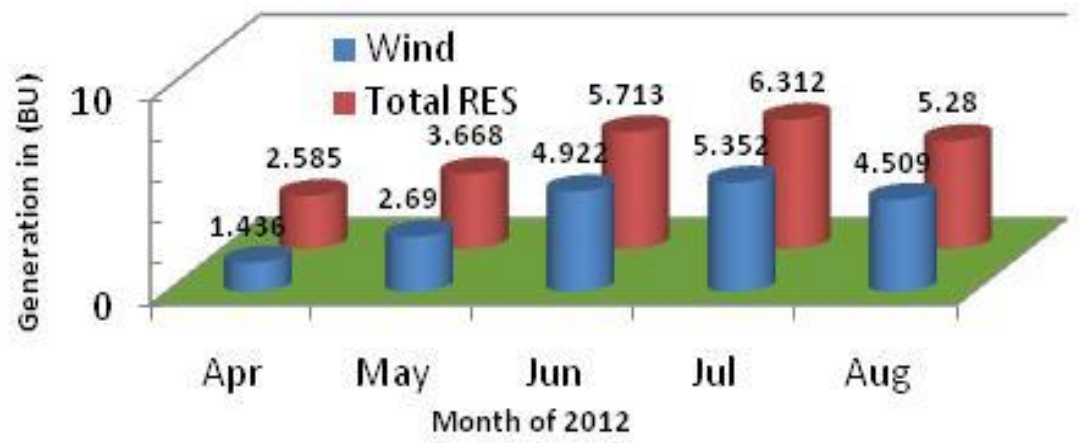

Data Courtesy: MNRE monthly report Aug'2012

Fig. 5 Monthly wind and cumulative RES generation from April to Aug, 2012. 
The breakup of contributions from various renewable sources in the total installed capacity as of end of Jan'2013 is illustrated in Fig. 7. Traditionally, most of the wind generation sites in India have been located in southern and western states. However, off late Rajasthan is attracting a lot of investment in wind power sector and a lot of wind farms are being commissioned in the desert state. Apart from these major wind power states Madhya Pradesh, West Bengal, Kerala and Goa are also making investments towards wind infrastructure. The wind power generation progress over a period of last decade in different important wind power states of India is shown in Table I.

The data in Table 1 interestingly reveals that five southern and western states of Gujarat, Maharashtra, Tamil Nadu, Andhra Pradesh and Karnataka had been contributing more than $90 \%$ of the country's wind power till about 2008. However, due to the progress shown by northern states of Rajasthan and Madhya Pradesh, the over domination of these states has slightly decreased to about $85 \%$. Out of all the up-coming states in wind generation Rajasthan is leading by some distance and is fast becoming one of the most important states on the wind map of India. The Rajasthan government wind policy envisages furthering its wind generation exploits by promoting installation of 100 MW electricity generation capacity from wind in Rajasthan over next three years (Anonymous 2013). Inspite of these developments the Indian wind generation scene pretty largely remains dominated by southern and western states with Tamil Nadu miles ahead of every other state of the country. The total installed wind power capacity of Tamil Nadu as on 31/3/2012 was 6987.6 MW. This makes Tamil Nadu the most important Wind Electricity Generation (WEG) state for the country.

Apart from the capacity addition one of the most important aspects of renewable energy is their environmental attribute. As per the C-WET assessment wind energy generation contributes to environmental saving by decreasing the effective $\mathrm{SO}_{\mathrm{x}}, \mathrm{NO}_{\mathrm{x}}$ and $\mathrm{CO}_{2}$

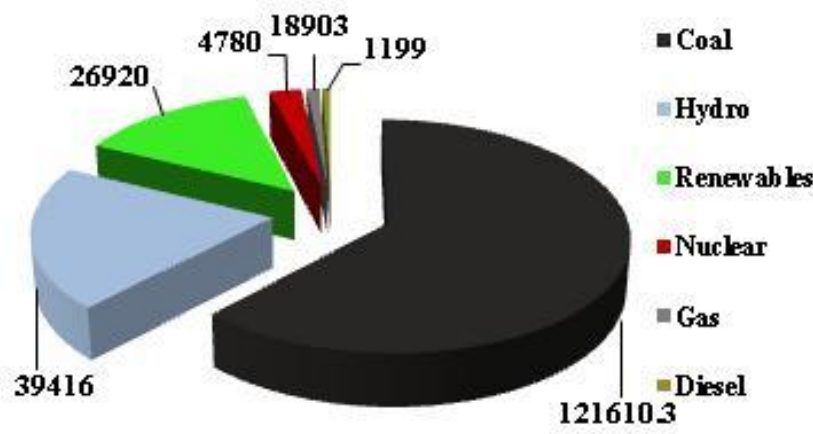

Fig. 6 Break up of total installed capacity (MW) of India emissions. The data of Table 2 gives an assessment of the pollution saving from WEG having an average output of 4,00,0.00 kWh per year.

In the initial phase of its development the wind installations were largely dependent on the imported technology and the hardware as the industry was still evolving. However, today the Indian wind manufacturing industry has gained the distinction of being third largest in the world. India is home to some of the biggest turbine manufacturers of the world such as Suzlon, ReGen Powertech, Kenersys, Vestas etc. who are implementing some of the best available technology.

\subsection{Wind Resource Assessment: Facts and Figures}

The planning of wind generation utilities involves study of wind patterns such as density, speed etc., on the basis of total land area available. This requires data collection and careful analysis of the accumulated data and its proper interpretation. In recent times there have been a lot of contradictions on figures proposed as wind energy potential in India. As per the initial official assessment of MNRE/C-WET the wind potential of India was estimated to be $49 \mathrm{GW}$ at $50 \mathrm{~m}$ hub height which was reviewed later on to $103 \mathrm{GW}$ at $80 \mathrm{~m}$ hub height. Contrary to this two recent studies conducted by different organizations put India's wind energy potential much beyond the official assessment of MNRE/C-WET. The first estimation was carried out by a group of experts belonging to Harvard University and the Technical Research Center of Finland (published in the Proceedings of the National Academy of Sciences) while the second by experts from The Energy Resources Institute (India). Both studies assessed the on-shore wind potential in India to be greater than 1,000 GW at the minimum hub-height of $80 \mathrm{~m}$ (GWEC, 2012). However, the findings of the study carried out by Amol Phadke et. al of Laurence Berkeley National Laboratory(LBNL),USA (Phadke et al. 2012) give a more comprehensive estimation of on-shore wind energy potential in India. The key findings of the study suggest that if a turbine installation density

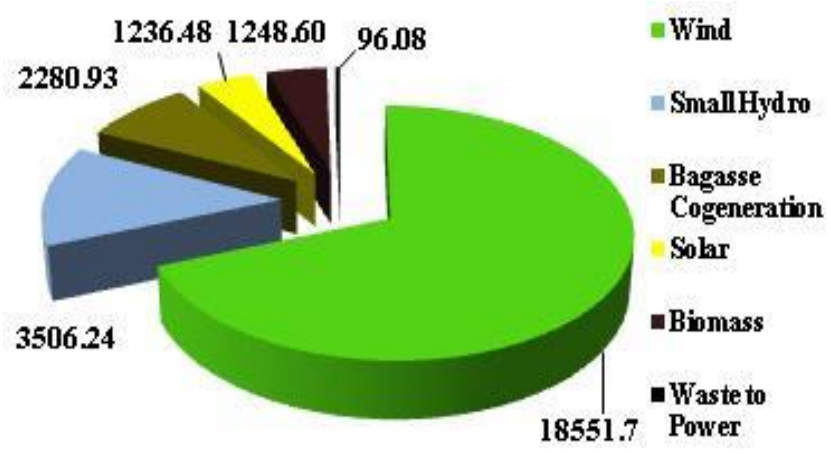

Fig. 7 Break up of renewable power installed capacity (MW) of India 
Citation: Khan, M.F. \& Khan, M.R. (2013), Wind Power Generation in India: Evolution, Trends and Prospects. Int. Journal of Renewable Energy Development, 2 (3) 2013: 175-186

$\mathrm{P}$ a g e $1 \mathbf{1 8 0}$

Table 1

Year wise wind power capacity addition of different Indian states since 2002.

\begin{tabular}{|c|c|c|c|c|c|c|c|c|c|c|c|}
\hline State & $\begin{array}{l}\text { Tamil } \\
\text { Nadu }\end{array}$ & $\begin{array}{l}\text { Andhra } \\
\text { Prad - } \\
\text { esh }\end{array}$ & Gujarat & $\begin{array}{l}\text { Karna- } \\
\text { taka }\end{array}$ & Kerala & $\begin{array}{l}\text { Madhya } \\
\text { Pradesh }\end{array}$ & $\begin{array}{l}\text { Rajast- } \\
\text { han }\end{array}$ & $\begin{array}{l}\text { W. } \\
\text { Bengal }\end{array}$ & $\begin{array}{l}\text { Mahara } \\
\text {-shtra }\end{array}$ & 0thers & Total \\
\hline $\begin{array}{l}\text { Up to } \\
\text { Mar'2002 }\end{array}$ & 877.0 & 93.2 & 181.4 & 69.3 & 2.0 & 23.2 & 16.1 & 1.1 & 400.3 & 3.2 & 1666.8 \\
\hline 2002-03 & 133.6 & 0.0 & 6.2 & 55.6 & 0.0 & 0.0 & 44.6 & 0.0 & 2.0 & 0.0 & 242.0 \\
\hline 2003-04 & 371.2 & 6.2 & 28.9 & 84.9 & 0.0 & 0.0 & 117.8 & 0.0 & 6.2 & 0.0 & 615.2 \\
\hline 2004-05 & 675.5 & 21.8 & 51.5 & 201.5 & 0.0 & 6.3 & 106.3 & 0.0 & 48.8 & 0.0 & 1111.7 \\
\hline 2005-06 & 857.55 & 0.45 & 84.60 & 143.80 & 0.0 & 11.40 & 73.27 & 0.0 & 545.10 & 0.0 & 1716.17 \\
\hline 2006-07 & 577.90 & 0.80 & 283.95 & 265.95 & 0.0 & 16.40 & 111.90 & 0.0 & 485.30 & 0.0 & 1742.05 \\
\hline 2007-08 & 380.67 & 0.0 & 616.36 & 190.30 & 8.50 & 130.39 & 68.95 & 0.0 & 268.15 & 0.0 & 1663.32 \\
\hline 2008-09 & 431.1 & 0.0 & 313.6 & 316.0 & 16.5 & 25.1 & 199.6 & 0.0 & 183.0 & 0.0 & 1484.9 \\
\hline 2009-10 & 602.2 & 13.6 & 197.1 & 145.4 & 0.8 & 16.6 & 350.0 & 0.0 & 138.9 & 0.0 & 1564.6 \\
\hline $2010-11$ & 997.4 & 55.4 & 312.8 & 254.1 & 7.4 & 46.5 & 436.7 & 0.0 & 239.1 & 0.0 & 2349.2 \\
\hline 2011-12 & 1083.5 & 54.1 & 789.9 & 206.7 & 0.0 & 100.5 & 545.7 & 0.0 & 416.5 & 0.0 & 3196.7 \\
\hline Total & 6987.6 & 245.5 & 2966.3 & 1933.5 & 35.1 & 376.40 & 2070.7 & 1.1 & 2733.3 & 3.20 & 17351.5 \\
\hline
\end{tabular}

Table 2

Annual Pollution savings from WEG systems in India

\begin{tabular}{cc}
\hline Pollutant & Annual Saving \\
\hline Sulphur - dioxide $\left(\mathrm{SO}_{2}\right)$ & 2 to 3.2 tonnes \\
Nitrogen - oxide $(\mathrm{NO})$ & 1.2 to 2.4 tonnes \\
Carbon - dioxide $\left(\mathrm{CO}_{2}\right)$ & 300 to 500 tonnes \\
Particulates & 150 to $280 \mathrm{~kg}$. \\
\hline
\end{tabular}

Data Courtesy: Center for Wind Energy Technology (C-WET)

of $9 \mathrm{MW} / \mathrm{KM}^{2}$ is presumed, the total wind potential of India comes out to be much greater at $2000 \mathrm{GW}$ to 3121 GW with the hub heights of $80 \mathrm{~m}$ and above with a capacity factor of $20 \%$ at $2 \%$ land availability. Acknowledging the new findings of Lawrence Berkley Lab the Ministry of New and Renewable Energy (MNRE) taking a positive step has signed MOU with the organization for proper resource assessment of on shore wind energy in India.

\subsection{Wind Turbines: Technologies and Innovations}

Various essential components of a wind turbine are illustrated in Fig. 8 (Molina \& Alvarez 2011). The growth achieved by the wind industry in terms of technology and capacity of turbines is quite substantial. Starting from imported 40 KW Wind Turbine Generating Systems (WTGS) in 1984 the unit sizes of $225 \mathrm{KW}$ to $1000 \mathrm{KW}$ with rotor diameters 60 to 70 meters were started to be developed indigenously by 2000 with the active R \& D initiatives of MNRE and CWET. The typical hub heights during the same era reached to about $70 \mathrm{~m}$. However, in last one decade the turbine development sector in India has grown at a very rapid pace. The wind turbines of more than $2000 \mathrm{KW}$ capacities are readily manufactured by the domestic manufacturers. Earlier, there were about five traditional manufacturers of wind turbines in India such as Suzlon, Vestas, Enercon, RRB Energy and Pioneer Wincon Pvt. Ltd. However, the growth registered by the wind sector lead to a number of new manufacturers entering the fray. Up-till Nov'2012, there were around 16 Indian manufacturers with a combined manufacturing capacity of $9500 \mathrm{MW}$. At least four new manufacturers are expected to introduce themselves in Indian market in the FY 2013-14 which will catapult the capacity to more than $10000 \mathrm{MW}$. Apart from this most of the established manufacturers in US and Europe having their subsidiaries in India are sourcing more than $80 \%$ of their orders from India. As of today Indian manufacturers are making almost all variants of wind turbines such as with gearless and geared drives coupled with synchronous, asynchronous and DFIG generating devices in a variety of hub heights and rotor diameters. A typical list of wind turbine specifications manufactured in India by various companies is given in Table 3. 


\subsection{Generators: Types and specifications}

The choice of generating device for wind turbines is one of the prime design considerations. The generators to be used for wind applications must be robust, cost effective, fault tolerant and should require minimum maintenance. These attributes are necessary for wind applications as the machines often have to work in hostile environments at isolated places which may be away from the immediate technical help. The modern wind turbine generators may be classified into following four categories (Li \& Chen 2008; Singh \& Surya 2011):

- Fixed-speed wind turbine generators (Type 1).

- Variable-slip, wind turbine generators with variable rotor resistance (Type 2).

- Doubly-fed induction generator (DFIG) wind turbine generators (Type 3).

- Full-converter wind turbine generators (Type 4). Each of these are herein discussed in brief.

\subsubsection{Fixed-speed wind turbine generator (Type 1):}

The fixed speed or type 1 wind turbine generators (WTGs) do not administer substantial controlling mechanisms and are often referred as self excited induction generators (SEIGs) due to absence of an exciter. They are squirrel caged induction machines and may be used both in isolated as well as grid connected modes. Whether operating in isolated or grid connected mode in both scenarios the main operational constraint is that they do not generate reactive power rather consume it and hence have an inherently poor voltage regulation (Khan et al. 2012a; Fraile-Ardanuy et al. 2012; Yang 2008). Thus, reactive power requirements of SEIGs to supply excitation as well as the loads they feed have to be met through some external means. The SEIGs are invariably supplied reactive power through static capacitors connected across their stator terminals (Khan et al. 2013b; Szabó et al. 2007). The voltage regulation, however, can be improved to a large extent by various means readily available such as series capacitances, statcoms, switched capacitors etc. (Ahshan \& Iqbal 2009; Chauhan et al. 2012; Khan et al. 2012b; Singh et al. 2004). Furthermore, because of their poor frequency and voltage regulations they are suited only for constant speed operations as both the generated voltage as well as frequency are very sensitive to speed variations. A general purpose induction motor of required variant ( 1 phase, 3 phase) and rating can be easily customized to act as a SEIG generator. The biggest attributes of SEIGs are that they are extremely rugged, maintenance free, economical and possess an inherent ability of self protection against short circuits and over loads as the excitation breaks down immediately under such transient conditions (Bansal 2005). The basic configuration of a three phase SEIG is shown in Fig. 9.

\subsubsection{Variable - slip, wind turbine generators with variable rotor resistance (Type 2):}

The type 2 (Li \& Chen 2008; Carballido 2009; Edward \& Ellis 2010) wind turbine generators work on optislip concept and are wound rotor induction machines with capability to offset the effects of variation in wind speed on generated power. The Danish manufacturer Vestas has been using this technology since 1990s (Hansen et al. 2001). The type 2 wind turbine generators are able to maintain constant output power at speeds higher than the rated speed by extracting slip power of the machine through a variable resistance connected in series with the rotor and dissipating the extracted power into heat through an external resistance. Typically, these generators can maintain constant output power up-to a speed variation of $10 \%$ above of the synchronous speed of machine (Hansen et al. 2007).

In the nominal and below nominal speed range their response is similar to type 1 generators. Presently, most of the modern wind turbine manufacturers are successfully implementing the technology in their designs. The fundamental approach of a type 2 WTG is depicted in Fig. 10.

\subsubsection{Doubly-fed induction generator (DFIG) wind turbine generator (Type 3):}

The doubly fed induction generators DFIGs (Boldea 2006; Tapia et al. 2003) are essentially the wound rotor induction machines. They have three phase windings both on stator and rotor and may be fed both on the stator as well as rotor windings which is why they are called doubly fed or double output induction generators. Typically DFIGs can work both in generating and motoring modes. However, for dual modes of operation the power electronic converters and the associated components should be capable of handling power in both directions. When operated as a generator, the DFIGs are capable of maintaining constant voltage and frequency over a wide range of variations in speed of wind turbine. This, attribute is especially useful for grid connected wind turbine generators. They are able to operate at constant 


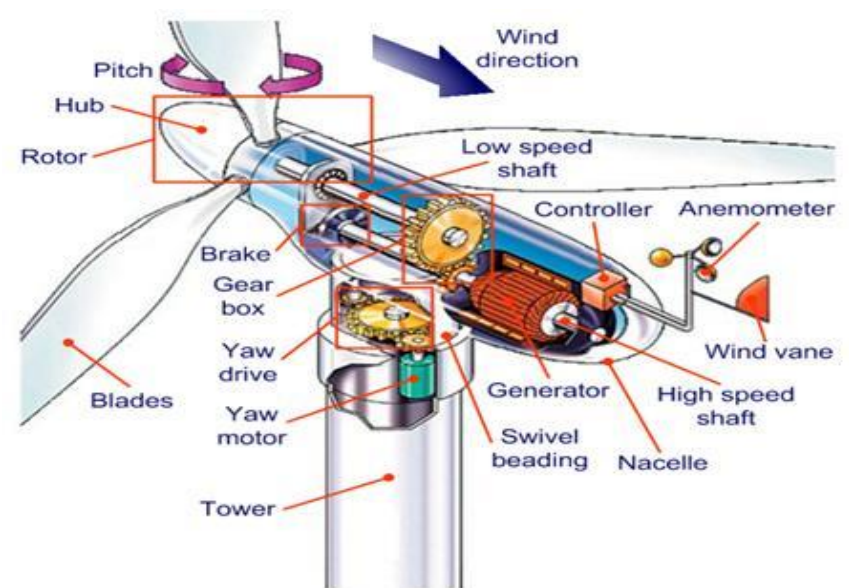

Fig. 8 Different parts of a wind turbine (Molina \& Alvarez 2011)

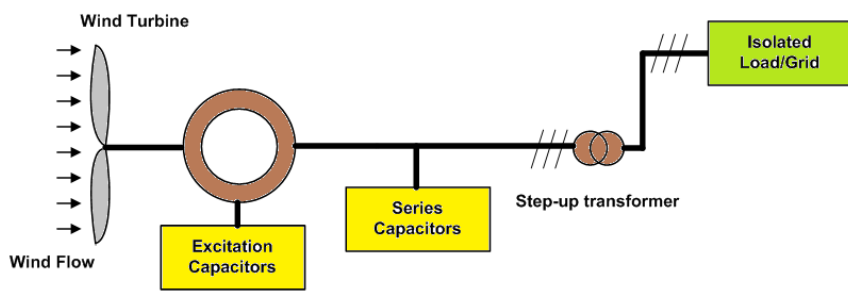

Fig. 9 Fixed speed wind turbine generator configuration

Table 3

Specifications of wind turbines manufactured by different manufacturers in India.

\begin{tabular}{|c|c|c|c|c|c|}
\hline Manufacturer & Rating(KW) & Drive & Speed & Generator & Class \\
\hline Enercon & 800 & Gearless & Variable & Synchronous & II-S \\
\hline GE Wind & 1,500 & Gear & Variable & DFIG & II A \\
\hline GE Wind & 1,600 & Gear & Variable & DFIG & II \\
\hline Suzlon & $1,250 / 2,100$ & Gear & Fixed & Asynchronous & II A/III \\
\hline Suzlon & 1,500 & Gear & Fixed & Asynchronous & III A \\
\hline Suzlon & 2,250 & Gear & Variable & DFIG & II B \\
\hline Vestas India & $1,650 / 1,800$ & Gear & Variable & Asynchronous & II B/ III A \\
\hline RRB Energy & 1,800 & Gear & Variable & Asynchronous & II/III \\
\hline Gamesa & 850 & Gear & Variable & DFIG & II A/III B \\
\hline Gamesa & 2,000 & Gear & Variable & DFIG & II A/III A \\
\hline Global Wind & 2,500 & Gear & Variable & Synchronous & III A \\
\hline Power Limited & & & & & \\
\hline Inox Wind & 2,000 & Gear & Variable & DFIG & III B \\
\hline Limited & & & & & \\
\hline Kenersys India & 2,000 & Gear & Variable & Synchronous & II A \\
\hline Leitner-Shriram & $1,350 / 1,500$ & Gearless & Variable & Synchronous & II A/III A \\
\hline ReGenPowertech & 1,500 & Gearless & Variable & Synchronous & III A/III B \\
\hline Win WinD & 1,000 & Gear & Variable & Synchronous & III B \\
\hline
\end{tabular}

frequency and voltage at variable turbine speeds by maintaining a continuous coordination with the grid. The basic configuration of a DFIG connected with wind turbine is shown in Fig. 11.

\subsubsection{Full-converter wind turbine generators (Type 4).}

The type 4 full- converter WTGs consist of full stage converters between the generator and the grid. They administer control on full power flowing between the electrical generator and the grid, unlike DFIGs which only control about $30 \%$ to $40 \%$ of the generated power, and hence are costly. The type 4 WTGs are able to effectively separate the generator from the grid which makes the fault response of the system very rapid as well as shields the generator from other transient grid disturbances. The inclusion of full converters provide greater flexibility with respect to variable speed operation as the WTG can operate with a wide range of turbine speeds facilitating higher power extraction. Due to the presence of full converters practically any type of generating machine such as SCIG, WRIG or WRSG may be used in type 2 WTGs as depicted in Fig. 12(a). However, the permanent magnet synchronous generators (PMSG) are considered to be the most suitable generating machines for type 2 WTGs. The PMSG have attracted a lot of attention in the recent past as they have done away requirement of an exciter and offer better torque-volume and torque-weight ratios. However, they are extremely restrictive in terms of the overload capabilities (Abbasian et al. 2011; Alemayehu 2011). 


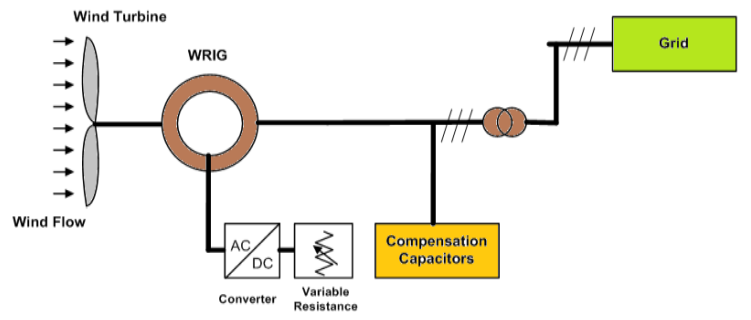

Fig. 10 Basic block diagram of a variable resistance WRIG

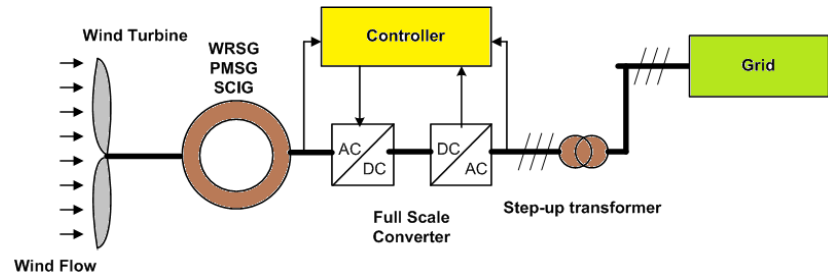

(a)

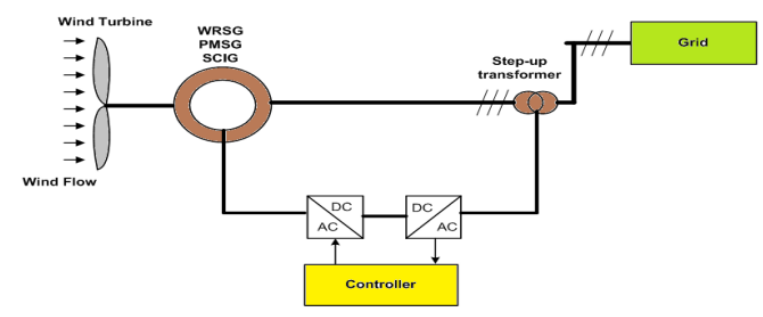

Fig. 11 Basic block diagram of a DFIG scheme for wind generation

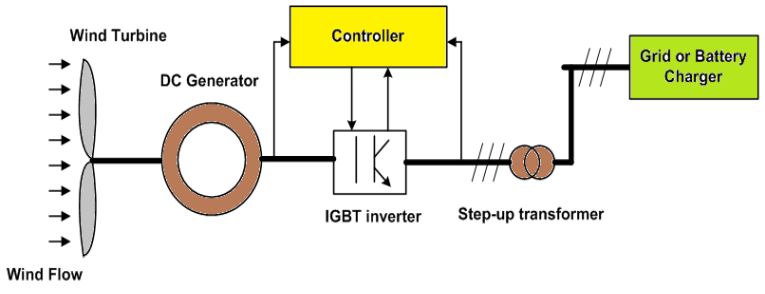

(b)

Fig. 12 Basic wind electricity generation system with full converter (a) with ac generators (b) with dc generator.

Off late, due to their easy availability and simple design the permanent magnet dc motors are gaining popularity for application in small scale wind turbines (Soe \& Wanna 2011; Atlam 2010). They also offer a suitable cost effective alternative as wind generator for portable wind turbines which is the latest concept in wind generation systems. A typical small scale wind turbine equipped with permanent magnet dc motor as generator with full converter is depicted in Fig. 12(b).

\section{Policies and their Implementation}

In respect of policies for the promotion of wind generation by way of obligatory legislations there was very little that could be brought over board till 2003. In spite of this wind power sector grew steadily due to the good work of Ministry of New and Renewable Energy. However, the year 2003 proved to be a milestone for wind sector policy environment. The electricity act 2003 included in it the binding laws and legislations for the development of renewable energy sources. The act made it obligatory for the federal and state governments as well as all the relevant agencies under their purview to promote renewable power sector. Consequent to these amendments in electricity act the government of India introduced a lot of useful schemes for the promotion of wind generation entities. Some of them are discussed in this section.

\subsection{Generation Based Incentives (GBI)}

The Generation Base Incentives (GBI) scheme was introduced in 2009 to encourage fresh investments by way of setting up new installations as well as capacity enhancement in the existing wind plants. As per the provisions of GBI all the wind installations are paid a subsidy of US 1 cent / kwh with a ceiling of 0.13 million USD. The Indian Renewable Energy Development Agency (IREDA) is mandated for all financial handling of disbursements. The amount is besides the energy tariff and is disbursed on half yearly basis. The scheme was to be rendered only to those wind plants installed up to 31st march. However, in 2012 the MNRE has recommended to Government for its continuation in 12th plan (2012-17) with provisions of review in the rate of incentive.

\subsection{Accelerated Depreciation (AD)}

It was introduced around 2009 and as per the provisions of $\mathrm{AD}$ a wind installation was allowed to right off up-to $100 \%$ (which was later reduced to $80 \%$ ) of its dept and other financial liabilities within first year of its commissioning. The provisions of scheme were to be made available only to those wind generation systems installed up to March' 2012. However, the success of this provision prompted the industry to lobby for its continuation in the sixth plan (2012-2017).

\subsection{Renewable energy Certificates (RECS)}

Apart from the GBI another policy which has been introduced is tradable Renewable Energy Certificates (RECs) which are granted by the government to wind power generation companies. It is a sought of certification that a specific wind generator has generated $1 \mathrm{MWh}$ of energy. The RECs can be traded in open market at the designated power exchanges recognized by the Central Electricity Regulatory Commission (CERC) the buyers may include DISCOMs or any open access consumer. The RECs generated in one state may be sold in any other states of India. This 
provision is especially useful for wind scarce states and enables them to fulfill their incumbent RPO targets.

\subsection{Renewable Purchase Specifications (RPS)}

Another problem faced with the wind sector in pre 2003 era was finding buyers and development of transmission infrastructure. The respective states did not take much interest towards this aspect due to the investments involved. However, the electricity act 2003 makes it mandatory for states to commit themselves to Renewable Purchase Specification (RPS) which is another mechanism introduced to ensure full utilization of power generated at renewable sites. Till the later part of 2012 about 26 states had committed their targets under RPS for the sourcing of power generated through renewable sources.

\subsection{Grid Integration Framework}

One of the major impediments in the growth of wind energy is proper grid connectivity. Various issues involved in the integration of wind utilities to grid may be put in two categories; the procedural and technical. Wind plants are sometimes also referred as "bad plants" (Yang 2007) as they produce variable power output. This imposes technical barriers on grid stability, safety and hence maintenance of grid efficiency by offsetting the adverse affects of the wind injected/drawn variable power. To deal with all the commercial and technical issues related to grid integration the Indian Electricity Grid Code (IEGC) brought a 'must-run' status for wind and solar generation systems in 2010 . The provisions of IEGC give leeway to wind generation entities on generation scheduling and the penalties levied on account of deviations from the schedule. The generators are responsible to pay the penalties only if the deviations are more than $\pm 30 \%$. For deviations less than this value the states have to bear the penalty.

\subsection{Tax and other benefits}

Besides, the generation based incentives there are several other benefits such as income tax benefits for a period of 10 years, reduction in VAT, exemption from excise duty for importing logistics and hardware. Apart from the tax benefits a very encouraging step taken by the authorities is allotment and leasing of forest land for the wind power projects with expedited provisions for land use conversion.

\section{Future of Wind Power in India}

As per the new policies scenario of global energy outlook 2012 the energy demand in India would reach 770 GW by 2035 (GWEC 2012). To achieve this target in stipulated time period the energy sector should grow at a Compounded Annual Growth Rate (CAGR) of 5.9\%. In terms of capacity it means that India has to add $20 \mathrm{GW}$ of power every year beginning from 2009. This is already proving to be quite a stiff target keeping in view that the highest generation achieved so far is $18 \mathrm{GW}$ in 2011-12. The wind generation which is largest constituent of renewable energy can ease out this burden if correct policy environment is created.

In order to exploit full potential of wind energy to achieve required growth rate of installed capacity the government had announced lots of good policies in 11th plan (2007-12) which have already been discussed in the preceding section. Out of these policy initiatives the provisions of Accelerated Depreciation (AD) and Generation Based Incentives (GBI) were the most appreciated ones by the wind fraternity. However, with the slowdown in economic growth the government of India decided to curtail both $\mathrm{AD}$ and GBI from financial year 2012-13 in spite of the recommendation of MNRE for their extension in 12th plan (2012-17) (MNRE 2013). There are conflicting views on the long term impacts of this decision on future of wind sector in the country with some (CII 2012) suggesting very little long term impacts while there are others claiming the decision to be retrograding for the wind industry. The long term impact assessment could only be done once an extensive set of data is available. However, the wind figures for FY 2012-13 suggest that actual generation may fall short of the target by a substantial amount. The country may be able to add only $1500 \mathrm{MW}$ of new generation capacity against a target of $2500 \mathrm{MW}$ set at the beginning of the year. As per the data from Central Electricity Authority (CEA), India has been able to add only 1068 MW of wind power up till Dec, 2012. Whether or not this decrease is solely due to policy withdrawals could be a matter of debate. But one can not contest the fact that both AD and GBI did attract lots of investment in wind sector in 11th plan period which is reflected by the excellent returns in the same period. Therefore, the chorus for the restoration of these policy mechanisms is growing with various bodies (Kasthoorirangaian 2012) asking for them to be reinstated.

Apart from the policy environment other issues which need deliberated and well targeted efforts are technical aspects of generation. One of the foremost issues is wind resource assessment. The initial estimates of wind availability by MNRE have been challenged by various studies. The Government citing the anomalies has already taken a positive decision of signing MOU with Lawrence Berkeley National Laboratory, USA for scientific studies and accurate assessment of wind availability in India. On the front of turbine manufacturing facilities and technology, India has made some substantial gains with the help of foreign investments and technology transfer schemes. Almost all the global manufacturing giants such as Suzlon, Gamesa, WindGen Powertech, Enercon, Seimens, GE etc. have made investments and are committed for the long term. India already acquires the 
distinction of being third largest wind market in the world.

Another avenue of wind generation which has been largely un- tapped in India is off shore generation. India has got about $7516 \mathrm{~km}$ of coast line at its disposal which can form a substantial contributor to wind capacity addition in future. The government has initiated work on making a comprehensive policy on off shore wind generation. An expert committee formed by the government in this regard made suggestions in Dec' 2012 for setting up off shore wind farms at Rameshwaran, Kanyakumari, Maharashtra, KeralaKonkan and Gujarat (Press Trust of India 2012). The MNRE on its part has formed a steering Committee which shall look after all the issues related to off shore wind generation. As per initial estimates Chennai alone has a potential of about $2 \mathrm{GW}$ off shore wind power (Samiran 2012), while there are $4.5 \mathrm{GW}$ capacity installations are planned for immediate commissioning. On the off shore policy front government is contemplating drafting the policy reminiscent to that being implemented for allocation of oil and gas resources in the country. The role of C-WET for future developments continues to be instrumental, it has already helped in increasing the number of wind monitoring stations to 701 by 31st, Jan' 13 (Centre for Wind Energy Technology 2013b) while certified turbine testing facilities in Kayathar are capable of testing wind turbines of more than $1250 \mathrm{KW}$ which may be enhanced on request.

The slow down being experienced by the sector in the current financial year remains a concern and it is extremely important for the industry to quickly pin point the specific reasons of poor showing. The government on its part would do well if the concerns of wind sector with respect to resurrection of policies such as $\mathrm{AD}$ and GBI are addressed at the earliest as wind power could contribute substantially not only in meeting the generation requirements but also in saving a lot of carbon credits for the country.

A very important aspect for the better design of wind turbines is improvement of generating devices. Most of the modeling of generators used for wind generation has been based on three phase designs. However, high phase (more than three phases) electric machines especially motors have been investigated thoroughly during the last few decades and are claimed to offer various advantages over three phase machines. The chief advantages of high phase machines are compact unit size, increased power output, better stability, less torque ripples and the reduced acoustic noise (Levi et al. 2007; Dabou et al. 2012; Levi 2008; Jones \& Levi 2002). Apart from these, the high phase machines offer certain attributes which are inherent to their structure, such as reducing the amplitude and increasing the frequency of torque pulsations, reducing the rotor harmonic current losses, and lowering the dc link current harmonics (Dabou et al. 2012). Therefore, possibility of exploring high phase technology for the design of wind generators is very imminent in current perspective for wind turbine generation systems. In past few years, the research on multiphase generators has picked up pace, however it's utility for wind generation is still very rare, especially in India. Thus it is proposed that high phase technology should be explored for wind generation. The authors of this paper are working towards the design and control of multiphase generators for wind energy applications and hope to contribute significantly towards development of multi phase generators for wind turbines.

\section{Conclusions}

Indian power sector has grown at a rapid pace in the post independence era. The installed capacity swelled from a paltry $2300 \mathrm{MW}$ in 1950 to about 211 GW by the end of 2012 . With the growing population it has always been a challenge for various governments to make sufficient and reliable power supply available to the users. In this paper a detailed research survey of various facets of wind power and its contribution towards meeting future demands is discussed in detail. In-spite of a late starter compared to established countries like USA, Denmark etc. India has achieved some important milestones in the last two decades. In the initial stages of wind plants development India received great help in terms of technology transfer and training from Denmark. In 1998 the country took a great leap by setting up the first dedicated organization for research and development on wind power in the form of Center for Wind Technology (C-WET). The CWET since its inception lead by example in setting up various turbine testing facilitates, conducting wind assessment studies, tariff determination exercises etc. With the remarkable increase shown by wind sector, India is fast becoming a manufacturing hub for wind turbines and currently acquires third largest market share in the world. This growth has also been driven by various good policies introduced by the government such as Accelerated Depreciation (AD), Generation Based Incentives (GBI), Renewable Energy Certificates (RECs), Renewable Purchase Obligation (RPO) etc. However, the decision of government to discontinue AD and GBI incentives is expected to have an adverse long term effect. On the technological aspects of wind generation the theory of high phase machines should be applied for improving the reliability and efficiency of generating machines for wind turbines.

\section{References}

Abbasian, M., Arash, H., Isfahani, Saeideh, S., Farid, S. (2011) Effects of Permanent Magnet Synchronous Generator and WindTurbine Parameters on the Performance of a Small-Scale Wind Power Generation System. PRZEGLĄD ELEKTROTECHNICZNY (Electrical Review) (87), 360-363 
Alemayehu, N.A. (2011) Multiphase Permanent Magnet Synchronous Generators For Offshore Wind Enegy System Control Of Six Phase Pmsg- Six Leg Converter System. M. S Dissertation, Norwegian University of Science and Technology.

Ahlstrom, A. (2005) Aeroelastic Simulation of Wind Turbine Dynamics, Doctoral Thesis, Royal Institute of Technology Department of Mechanics SE-100 44 Stockholm, Sweden.

Ahshan, R. \& Iqbal, M.T. (2009) Voltage Controller of a Single Phase Self-Excited Induction Generator. The Open Renewable Energy Journal (2), 84-90.

Al-Majed, S.I. \& Fujigaki, T. (2010) Wind Power Generation: An Overview. Paper presented at the Modern Electric Power Systems Symposium, Wroclaw University of Technology, Wroclaw Poland, September 20-22, Pap_ID:80.

Anonymous (2012) UK: Greater Gabbard Offshore Wind Farm Generates Power, Retrieved from http://www.offshorewind.biz /2012/09/07/uk-greater-gabbard-offshore-wind-farm-generat es-power/ accessed on February 5,2013.

Anonymous (2013). Retrieved from Mop.rajasthan.gov.in/ wind_policy.asp accessed on March 8, 2013.

Atlam, 0. (2010) A small scale education experiment kit with wind generator-PEM electrolyser system and modeling. Turkish Jornal of Electrical Engineering \& Comp Science, 18(4): DOI: 10.3906/elk-0812-18.

Athanas, A.K. \& McCormick, N. (2013) Clean energy that safeguards ecosystems and livelihoods: Integrated assessments to unleash full sustainable potential for renewable energy. Renewable Energy (49), 25-48

Bansal, R.C. (2005) Three-Phase Self-Excited Induction Generators: An Overview. IEEE Transactions on Energy Conversion, 20(2), 292 299.

Boldea, I. (2006) Variable Speed Generators. The Electric Generators Handbook by Taylor \& Francis Group, LLC.

Bob, Y. (2013) Japan to replace nuclear plant with world's largest wind farm, an article accessed on line at http://phys.org.

Carballido, H.A.L. (2009) Control of a wind turbine equipped with a variable rotor resistance: Thesis For The Degree of Master of Science, Department of Energy and Environment, Division of Electric Power Engineering, Chalmers University of Technology, Göteborg, Sweden, May 2009.

Carlin, P.W., Laxson, A.S., \& Muljadi, E.B. (2003), The History and State of the Art of Variable-Speed wind Turbine Technology, Wind Energy, Wind Energ. 6, 129-159.

Centre for Wind Energy Technology. (2013a) The Charter. Retrieved from www.cwet.tn.nic.in/html/ aboutus_charter.html, accessed on January 15, 2013.

Centre for Wind Energy Technology. (2013b) List of Monitoring Stations. Retrieved from www.cwet.tn.nic.in $/ \mathrm{html} /$ departments_wms.html accessed on February 15, 2013.

Chaubey, R.N. \& Saket, R.K. (2012) Development of a cost effective wind power generation system: an overview. International Journal of Research and Reviews in Applied Sciences, 10(3), 472-480

Chauhan, Y.K., Sanjay, K.J., \& Bhim, S. (2012) Performance of selfexcited induction generator with cost effective static compensator. Maejo International Journal of Science Technology, 6(01), 12-27.

CII (Confederation of Indian Industry) Karnataka Conference on Power. (2012) Sustainable Power through Renewable Sources, Aug'2012", A Report, available at http://www.pwc.in/assets / pdfs/grid/renewable-energy/cii-report_-240812-sustainable-po wer-through-renewable-energy-updated.pdf, accessed on $10 / 3 / 13$.

Dabou, S.M., Abd El-Wahab, H. \& Essam M.R. (2012) Five-Phase Induction Motor Drive System Fed from Five-Phase Matrix Converter. Paper presented at the IEEE 15th International Middle East Power Systems Conference (MEPCON'12), Alexandria University, Egypt, December 23-25, Paper ID 302, pp 898-903.

Dahlquist, E., Iana, V., Fredrik, W., Eva, T., \& Jinyue, Y. (2011) Optimization of the Energy System to Achieve a National Balance Without Fossil Fuels. International Journal of Green Energy, Taylor and Francis Group, (8), 684-704
Earnest, J. \& Tore, W. (2011) Wind Power in India, In the Book "Wind Power Plants and Projects Development." by PHI Learning Pvt. Ltd, New Delhi India.

Edward, M., \& Ellis, A. (2010) Wecc Wind Generator Development: Final Project Report. Prepared for CIEE By:National Renewable Energy Laboratory.

Eriksson, S., Hans, B., Mats, L. (2008) Evaluation of different turbine concepts for wind power, Renewable and Sustainable Energy Reviews 12, 1419-1434.

Fraile-Ardanuy, J., Jesus, F.M., Pedro A., Garcia-Gutierrez. (2012) Voltage control of isolated self-excited induction generator through series compensation. Prezglad electrotechniczny (Electrical review), (R.88) NR 1a:132-136.

Gasch, R. \& Twele, J. (eds.) (2012) Wind Power Plants: Fundamentals, Design, Construction 15 and Operatio, (C) Springer-Verlag Berlin Heidelberg, DOI 10.1007/978-3-642-22938-1_2.

GWEC (Global Wind Energy Council). (2012) India Wind Energy Outlook -2012, November' 2012. Available at gwec. net, accessed on $31 / 01 / 13$

GWEC (Global Wind Energy Council). (2013) Global Wind Statistics2012 dated 11/02/2013. available at http://www.gwec.net/wpcontent / uploads /2013/02/GWEC - PRstats- 2012_english.pdf, accessed on 16/02/2013.

Hansen, L.H., Helle, L., Blaabjerg, F., Ritchie, E., MunkNielsen, S., Bindner, H., S־rensen, P., \& Bak-Jensen, B. (2001) Conceptual survey of generators and power electronics for wind turbines. Riso National Laboratory Technical Report Riso-R-1205(EN) Roskilde, Denmark.

Hansen, A.H., Hansen, L.H. (2007) Wind turbine concept market penetration over 10 years 1995-2004). Wind Energy, 10(1), 8197.

Hinrichs-Rahlwes, R. (2013) Renewable energy: Paving the way towards sustainable energy security: Lessons learnt from Germany. Renewable Energy 49, 10-14.

Jones, M. \&Levi, E. (2002) A literature survey of state-of-the-art in multiphase AC drives. Paper presented at the 37th International Universities Power Engineering Conference UPEC, Stafford, UK, CD-ROM Paper No. 46, pp. 505-510.

Kaldellis, J.K. \& Zafirakis, D. (2011) The wind energy (r)evolution: A short review of a long history. Renewable Energy, 36, 1887-1901.

Kasthoorirangaian, K. (2012) Post budget Memorandum - Request for Continuation of Accelerated Depreciation in Budget for 2012. Letter addressed to Hon'able Finance Minister of India by Indian Wind Power Association, WINDPRO Magazine, 174:3, available at www.windpro.org/pdf/Windpro Magazine - April 2012.pdf accessed on March 10, 2013.

Khan, M.F. \& Khan, M.R. (2013)a. Various Facets of Wind Power. International Journal of Applied Engineering Research, (3)8: 7074.

Khan, M.F. \& Khan, M.R., Atif, I. (2012) A Optimal Capacitance (Shunt) Required for a Self Excited Single Phase Induction Generator. Paper presented at the Int. Conf. On Emerg. Trend. in Engg. and Tech, TMU, India, April 6-7, ID:118.

Khan, M.F. \& Khan, M.R., Atif. I. (2012)b Performance Analysis of Shunt, Short Shunt and Long Shunt Self Excited Induction Generator. Poster presented at the IEEE International conference on Power Electronics Drives and Energy Systems, IISc Bangalore, India, December 16-19, IEEE Xplore DOI: 10.1109 /PEDES .2012 .6484478

Khan, M. R, Khan, M. F., Iqbal ,A. (2013)b. Investigation on Resonating Behaviour of a Self Excited Induction Generator. in the proceedings of IEEE Tencon-Spring, April 17-19, Sydney, Australia, Pap_ID:p82.

Levi, E., Bojoi, R., Profumo, F., Tolyat, H.A., \& Williamson, S. (2007) Multiphase induction motor drives - a technology status review. Electric Power Application, IET (1), 489-516.

Levi, E. (2008) Multi- phase machines for variable speed applications. IEEE Transaction on Industrial Electronics, (5) 55, 1893-1909.

Li, H. \& Chen, Z. (2008) Overview of different wind generator systems and their Comparisons, IET Renew. Power Gener., 2(2), 123-138.

List of onshore wind farms (n.d) available at www. eendragt-wind.nl /list-of-onshore -windfamrs.ht ml, accessed on January 09, 2013. 
Manwell, J.F., McGowan, J.G, \&Rogers, A.L. (2002) Wind energy explained 1st ed. Amherst, USA: Wiley.

MNRE (2013) Strategic Plan for New and Renewable Energy Sector for the Period 2011-17. A report accessed available at http://mnre.gov.in/file-manager /UserFiles/strategic_ plan_mnre 2011_17.pdf accessed on February 20, 2013.

Molina, M.G. \& Alvarez, J.M.G. (2011) Technical and Regulatory Exigencies for Grid Connection of Wind Generation, Energy Engineering, Retrieved from www. intechopen. com /source $/ \mathrm{html} / 17118 /$ media/ image2.png downloaded on February 15, 2013.

Okundamiya, M.S. \& Nzeakoba, A.N. (2012) Model for Optimal Sizing of a Wind Energy Conversion System for Green Mobile Applications. International Journal of Green Energy, Taylor and Francis Group, (10), 205-218.

Press Trust of India. (2012) Off shore farms to harness wind energy in India. The Economic Times available at http:// articles. economictimes .indiatimes.com/2012-12-10/news /35726603 1 wind-energy-offshore-wind-wind-farms, accessed on 19/02/ 2013.

Price, T.J. (2005) James Blyth- Britain's first modern wind power pioneer. Wind Engineering, (3)29, 191-200

Madsen, P. H (n.d) India, Danida and RISO. Wind Energy Department, RISO National Laboratory available at www.risoe.dk/rispubl/SYS/syspdf/... /session 14_madsenpre. pd. accessed on January 10, 2013.

Phadke, A., Ranjit, B., Jagmeet, K. (2012) Reassessing Wind Potential Estimates: Economic and Policy Implications. March-2012, International Energy Studies, Technologies Division Environmental Energy, Berkeley Lab, USA, available at http://ies.lbl.gov/node/473, accessed on 22/2/13.

Sanaeepur, S., Hamidreza, S., Ali, K. \& Habibi, M.H. (2013) Renewable energies: climate-change mitigation and international climate policy. International Journal of Sustainable Energy, Taylor \& Francis, London, UK.
Satyaraj, J.J. (2013) First Wind Farm Lies in a State of Neglect, a news report, available at http://ibnlive.in.com/news/first-wind-farmlies-in-state-of-neglect/157065-60-118.html, accessed on $04 / 02 / 2013$.

Samiran S. (2012) Offshore wind energy policy in the offing. Indian Express available at http:// newindianexpress .com / business/news/article583696.ece, accessed on 19/02/13.

Singh, B., Murthy, S.S. \& Sushma, G. (2004) Analysis and Design of STATCOM-Based Voltage Regulator for Self-Excited Induction Generators. IEEE Transactions on Energy Conversion, (4)19, 783790.

Singh, M. \& Surya, S. (2011) Dynamic Models for Wind Turbines and Wind Power Plants: Subcontract Report NREL/SR-5500-52780, The University of Texas at Austin Austin, Texas, USA.

Soe, K. A. \& Wanna, S. (2011) Construction and Performance Testing of Small-Scale Wind Power System. World Academy of Science, Engineering and Technology, (51), 156-160.

Szabó, L., Károly, Á. BIRó, Cosmina, N., Florin, J. (2007) Useful Simulation Tool for Induction Generators Used In Wind Power Plants. (C2007 IEEE, pp 574-579, available at www. researchgate.net/ Useful Simulation Tool for Induction Generators Used In Wind Power Plants.

Tapia, A., Tapia, G., J. Ostolaza, X., \& Sáenz, J.R. (2003) Modeling and Control of a Wind Turbine Driven Doubly Fed Induction Generator. IEEE Transactions of Energy Conversion, (2)18, 194204.

Yang T. C. (2008) An Initial Study of Using Rechargeable Batteries in Wind Power Generation with Variable Speed Induction Generators. IET proceedings: Renewable Power Generations, (2)2, 89-101.

Yang, T.C. (2007) A Novel Design to Enable Higher Penetration of Wind Power. Paper presented at the European Offshore Wind Conference \& Exhibition, Berlin, Germany, December 4-6 